\title{
Natural History of Ehrlichia ruminantium
}

Basil A. Allsopp

Department of Veterinary Tropical Diseases, Faculty of Veterinary Science, University of Pretoria, Private Bag X04, Onderstepoort 0110, South Africa.

Corresponding author:

Basil A. Allsopp

Department of Veterinary Tropical Diseases

Faculty of Veterinary Science, University of Pretoria

Private Bag X04, Onderstepoort 0110, South Africa

Tel +27 125298426

Fax +27125298312

E-mail Basil.Allsopp@up.ac.za

Keywords: Ehrlichia ruminantium, heartwater, distribution, epidemiology, virulence, vaccine development. 


\section{Abstract}

Ehrlichia ruminantium is an obligately intra-cellular $\alpha$-proteobacterium which causes a disease known as heartwater or cowdriosis in some wild, and all domestic, ruminants. The organism is transmitted by ticks of the genus Amblyomma, and it is of serious economic importance wherever the natural vectors occur, an area which includes all of sub-Saharan Africa, and several islands in the Caribbean. The disease was first recognized in South Africa in the $19^{\text {th }}$ century, where its tick borne nature was determined in 1900, but the organism itself was not demonstrated until 1925, when it was recognized to be a rickettsia, initially named Rickettsia ruminantium. It was thus the first species of what are now known as Ehrlichia to be discovered, and most of the early work to elucidate the nature of the organisms, and its reservoirs and vectors, was performed in South Africa. The next milestone was the development, in 1945, of an infection and treatment regimen to immunize livestock, and this is still the only commercially available "vaccine" against the disease. Then in 1985, after fruitless attempts over many years, the organism was propagated reliably in tissue culture, opening the way for the first application of the newly developed techniques of molecular genetics. From 1990 onwards the pace of heartwater research accelerated rapidly, with notable advances in phylogeny, diagnosis, epidemiology, immunology, and vaccine development. The complete genome sequence was published in 2005 , and during the last two years a new understanding has arisen of the remarkable genetic variability of the organism and new experimental vaccines have been developed. Despite all this the goal of producing an effective vaccine against the disease in the field still remains frustratingly just beyond reach. This article summarises our current understanding of the nature of $E$. ruminantium, at a time when the prospects for the development of an effective vaccine against the organism seem better than at any time since its discovery 83 years ago. 


\section{Introduction}

Ehrlichia ruminantium, which is carried by ticks of the genus Amblyomma, causes the disease known as heartwater or cowdriosis in cattle, sheep, goats and some wild ruminants. The disease occurs throughout sub-Saharan Africa and also on the French Antillean islands of Guadeloupe, Antigua and Marie Galante, to which infected Amblyomma variegatum ticks were introduced, possibly as early as the eighteenth century (Maillard and Maillard, 1998). The map in Figure 1 shows the areas at risk from heartwater in sub-Saharan Africa, with the approximate numbers of domestic ruminants in those areas. The total is approximately $150,000,000$ animals at risk, of which $114,000,000$ (76\%) are in the red areas of greatest potential exposure to tick challenge. Heartwater has an average incubation period in susceptible animals of less than 2 weeks (Van de Pypekamp and Prozesky, 1987), adult cattle have a subsequent mortality of up to $82 \%$ (Du Plessis and Malan, 1987b) and Merino sheep of up to 95\% (Neitz, 1964). The disease is a major obstacle to the introduction of high-producing animals into sub-Saharan Africa to upgrade local stock, and is of particular importance when susceptible animals are moved from heartwater-free to heartwater-infected areas (Simpson et al., 1987). The occurrence of heartwater is frequently taken for granted in the endemic areas of Africa, and definitive diagnoses are not often performed. The economic impact of the disease is therefore difficult to quantify, although estimates which have been made indicate that the losses can be enormous (Mukhebi et al., 1999). Whatever the actual costs may be it is certain that the economic importance of heartwater in Africa is comparable to that of East Coast fever, trypanosomosis, rinderpest, and dermatophilosis (Provost and Bezuidenhout, 1987). It is not surprising, therefore, that the possibility that the disease could spread from the Antillean islands to the American mainland, where a suitable tick vector is already present, is perceived as a constant threat for American livestock industries (Deem, 1998). 


\section{The Organism}

Heartwater was recognized to be a tick-borne infection in 1900 (Lounsbury, 1900) but it was not until 1926 that the causative agent was identified as a rickettsia, originally named Rickettsia ruminantium (Cowdry, 1925a; Cowdry, 1925b), and subsequently renamed Cowdria ruminantium (Moshkovski, 1947). The advent of molecular phylogenetics has led to reorganisation of the order Rickettsiales into two families, the Rickettsiaceae and the Anaplasmataceae, and reclassification of the genera in those families (Dumler et al., 2001). E. ruminantium, long thought to be the sole species in the genus Cowdria, is now recognized to be a typical species of Ehrlichia in the family Anaplasmataceae. The type specimen of $E$. ruminantium is the Welgevonden genotype (Du Plessis, 1985) which was obtained from an Amblyomma hebraeum tick collected in the same geographical area as the originally identified causative agent of heartwater (Cowdry, 1925a).

E. ruminantium is a Gram negative bacterium which stains purplish-blue with Giemsa (Cowdry, 1925a; Cowdry, 1925b). In common with all species in the family Anaplasmataceae growth takes place in an intracellular vacuole bounded by a lipid bilayer membrane derived from the eukaryotic host cell membrane (Dumler et al., 2001). The bacteria are mostly coccoid and vary in size from small $(0.4 \mu \mathrm{m})$, through medium $(0.76 \mu \mathrm{m})$, to large $(1.04 \mu \mathrm{m})$ and occasionally very large $(>1.04 \mu \mathrm{m})$ (Pienaar, 1970). In colonies containing very large organisms pleomorphic forms (horseshoe, ring and bacillary shaped) occur (Pienaar, 1970). Individual E. ruminantium cells, in common with other Gram negative bacterial cells (Beveridge and Davies, 1983), are bounded by two membranes, an inner (plasma) membrane and an outer membrane. Internally the greater part of the inner structures of small and intermediate-sized cells contain electron-dense material and these are referred to as dense-cored cells or elementary bodies. Electron-pale areas dominate the inner structure of large and very large organisms, which are referred to as reticulated bodies. Organisms of intermediate size and electron density are often referred to as intermediate bodies (Jongejan et al., 1991; Pienaar, 1970; Prozesky, 1987a).

\section{Replication Cycle}

E. ruminantium replicates mainly by binary fission of reticulated bodies (Kocan et al., 1987a; Pienaar, 1970; Prozesky et al., 1986; Prozesky and Du Plessis, 1985) while 
the elementary bodies represent the infective stage (Jongejan et al., 1991). Sequential development of the organism has been described in both vertebrate (Du Plessis, 1982) and invertebrate host cells (Kocan et al., 1987a). Transmission electron microscopic studies of in vitro cultivated $E$. ruminantium have revealed the presence of intracellular reticulate bodies two to four days post-infection, and intermediate bodies four to five days post-infection. Large numbers of elementary bodies are seen after rupture of endothelial cells five to six days after infection (Jongejan et al., 1991).

In the mammalian host the organism initially replicates in reticulo-endothelial cells in lymph nodes, and rupture of these cells releases elementary bodies which then infect endothelial cells (Du Plessis, 1970). After entry into the endothelial cell, by a process resembling phagocytosis, each organism develops within a vacuole to form a colony, a process which eventually leads to rupture of the cell. This disseminates elementary bodies into the bloodstream to continue the infection cycle (Prozesky and Du Plessis, 1987).

\section{Epidemiology}

The epidemiology of heartwater depends upon many interacting circumstances, few of which are entirely quantifiable. Important factors are: the number and susceptibility of available vertebrate hosts; the populations and infection rates in the tick vectors; seasonal variations in tick abundance and activity; dissemination of infected ticks and ruminants; mechanisms operating during tick-host transmission; and the characteristics of different strains of the causative organism. We will look briefly at some of these factors.

\section{Vertebrate Reservoirs}

E. ruminantium appears to have evolved in southern Africa (Allsopp et al., 2003) and African wild ruminants are probably the original reservoir of the disease (Neitz, 1967). Fifteen species of wild African ruminants have been shown to be susceptible to infection, either naturally or experimentally (Table 1). In southern Africa the most important wild ruminant reservoirs are probably blesbuck, black wildebeest (Neitz, 1935), African buffalo (Allsopp et al., 1999; Andrew and Norval, 1989a) and eland (Wesonga et al., 2001). The existence of a wild ruminant reservoir is not essential for maintenance of the disease which can be entirely maintained in a domestic stock population as seen in 
Madagascar, Guadeloupe and São Tomé (Uilenberg, 1983). Ten species of non-African ruminants are also known to be susceptible (Table 1), including the very widely distributed American white-tailed deer (Odocoileus virginianus).

Non-ruminant vertebrate reservoirs of the organism may play a minor role in the epidemiology of heartwater, but the available information is not conclusive. For instance, it has been reported that helmeted guinea fowl (Numida meleagris), leopard tortoise (Geochelone pardalis) and scrub hare (Lepus saxitilis) can harbour E. ruminantium subclinically, and that larvae and nymphs of $A$. hebraeum which feed on them become infectious at the following instar (Bezuidenhout, 1988). Nothing is known, however, about the importance of these non-ruminants as reservoirs of infection, and in fact other workers have been unable to replicate these findings (Peter et al., 2001). The multimamate mouse (Mastomys coucha) (MacKenzie and McHardy, 1987) and the striped mouse (Rhabdomys pumilio) (Hudson and Henderson, 1941) are susceptible to infection with E. ruminantium, but Amblyomma ticks are not believed to feed on rodents in the wild so they are unlikely to act as natural heartwater reservoirs (Howell et al., 1989).

\section{Tick Vectors}

E. ruminantium is transmitted by ticks of the genus Amblyomma and the distribution of heartwater in Africa coincides with that of the vector species. The heartwater endemic area includes almost the whole of sub-Saharan Africa, except for the very dry south west, as well as the offshore islands of Madagascar, Mauritius, Reunion, Grande Comore and São Tomé (Du Plessis et al., 1989; Provost and Bezuidenhout, 1987). Ten Amblyomma spp. capable of transmitting the organism occur in Africa. The most important vectors are $A$. variegatum and $A$. hebraeum (Bezuidenhout, 1987) but $A$. pomposum, A. lepidum A. astrion, A. cohaerens, A. gemma (Walker and Olwage, 1987) and $A$. marmoreum (Peter et al., 2000) can also be significant vectors. A. hebraeum is the main vector of heartwater in southern Africa, while $A$. variegatum, the most widely distributed vector in Africa, has become established in the Caribbean where it transmits the disease on 3 islands, Guadeloupe, Antigua and Marie Galante (Molia et al., 2008; Uilenberg et al., 1984). A. maculatum is the only native American species of Amblyomma known to be an effective vector of $E$. ruminantium, having a vector potency in sheep similar to that of $A$. variegatum (Mahan et al., 2000). 
The vectors of heartwater are three-host ticks, and the organism is transmitted transstadially. Both nymphs and adults become infected with $E$. ruminantium after two days of feeding on infected sheep (Bezuidenhout, 1988) or two to four days of feeding on infected goats (Camus and Barré, 1992). A single infected nymph can cause a fatal infection in a susceptible animal (Lounsbury, 1902) and intrastadial transmission by male A. hebraeum ticks moving from sick to susceptible animals also occurs (Andrew and Norval, 1989b).

\section{Transmission}

The effectiveness of Amblyomma ticks as vectors of heartwater in an area depends on their vector efficiency, their distribution, their activity and abundance, and their adaptation to local wild or domestic carriers of E. ruminantium (Uilenberg, 1983). The tick population in an area is heavily influenced by temperature and humidity (Petney et al., 1987), and in the drier parts of Africa this frequently leads to an increased incidence of heartwater after good rains when peak numbers of ticks are present. In regions where the climate is temperate and the rainy season is not well defined the occurrence of heartwater is not really seasonal, this is especially true in the Caribbean (Camus, 1987).

Apparently healthy ruminant hosts, carrying E. ruminantium organisms at very low levels, can be infective to ticks for long periods, at least 361 days for cattle (Andrew and Norval, 1989a) and 11 months for goats (Camus, 1992). In the latter case the levels of the organism were so low that the carriers only infected the ticks intermittently during the 11 month period of the experiment, demonstrating the danger which is posed by the movement of heartwater carrier animals to areas free from the disease.

Ticks in the field in heartwater endemic areas exhibit surprisingly low infection rates with $E$. ruminantium. For $A$. hebraeum the rates have been found to be $1-7 \%$ in South Africa (Allsopp et al., 1999; Du Plessis and Malan, 1987c) and 8.5-11.2\% in Zimbabwe (Peter et al., 1999), while rates of $1.2-13.3 \%$ were seen in A. variegatum in Senegal (Gueye et al., 1993). The highest rate which has been reported is $19.1 \%$ for A. variegatum in Maria Galante (Molia et al., 2008). When A. variegatum larvae and nymphs were fed experimentally on E. ruminantium-infected sheep, however, infection rates of $100 \%$ were seen in the ticks at the following instar (Gueye et al., 1993), which 
suggests that in the field many ticks feed during the larval or nymphal stages on non-susceptible or non-infected hosts.

Several factors may help to explain how relatively small numbers of infected ticks can maintain the heartwater infection in a particular area. While infected larvae or nymphs only become infective after moulting to the next instar, they then remain infective for life (Camus and Barré, 1992; Neitz, 1968). E. ruminantium-infective ticks in the field present a highly virulent disease challenge, much more virulent than that presented by elementary bodies contained in an experimental needle challenge with infected blood (Collins et al., 2003; Pretorius et al., 2008). Vertical transmission of heartwater from dams to their calves has been demonstrated in cattle in Zimbabwe (Deem et al., 1996). Infected cells in the colostrum are thought to be responsible for this phenomenon, and it may be assumed that the same mechanism operates in other wild and domestic ruminants. Although the prevalence of vertical transmission has not been quantitatively estimated it must have an important effect on the maintenance of the disease.

\section{The Tick-Host-Pathogen Interface}

Infected but unfed ticks are not infective until after they have fed for $38 \mathrm{~h}$ (nymphs) or 75h (adults) (Bezuidenhout, 1987), and this so-called 'grace period' has been observed with other tick-borne pathogens. Ticks undergo long periods of metabolic inactivity while waiting for their next blood meal, and it has been speculated that, in the case of $A$. phagocytophilum, the parasites remain dormant during these periods, and are then activated when feeding begins, possibly in response to temperature changes and/or to chemical signals from host blood (Katavolos et al., 1998). In the case of E. ruminantium temperature may not to be the trigger, since warming of infected ticks to $37^{\circ} \mathrm{C}$ without allowing them to feed does not induce infectivity (Bezuidenhout, 1987).

We noted above that E. ruminantium organisms delivered by infective tick challenge are much more virulent than elementary bodies delivered as an infected blood needle challenge (Collins et al., 2003; Pretorius et al., 2008). This enhanced virulence must therefore develop during the grace period, but there is currently no experimental information about the mechanisms involved. During the grace period one would expect E. ruminantium to be up-regulating metabolic pathways and other genes which lead to enhanced survival in the mammalian host. The genes involved may be those of the 
pathogen, the tick, or the mammal, and pointers from experiments on other ticks and parasites indicate the sorts of changes which may be taking place. It is known, for instance, that the saliva of Ixodes scapularis and Rhipicephalus sanguineus ticks contain molecules which modulate the activity of the mammalian immune system and thereby enhance the survival of transmitted parasites (Ferreira and Silva, 1998; Wikel, 1999; Zeidner et al., 1997). Other mechanisms involve parasite surface changes which are activated only during tick feeding, and the most sophisticated example currently known is that of Borrelia burgdorferi, the Lyme disease agent, which is maintained in an Ixodes scapularis-mouse cycle. During tick feeding the parasite stimulates the upregulation of a tick salivary gland protein which binds specifically to an outer surface protein on the spirochaete. This protein complex then protects the parasite from antibody-mediated killing after it had been injected into mice which had previously been infected by the same organism (Ramamoorthi et al., 2005). The mechanisms operating at the tick-hostpathogen interface in the case of E. ruminantium, whatever they may be, are unlikely to be any less elaborate and they are important potential subjects for future genomic and proteomic-based investigation.

\section{E. ruminantium and $A$. variegatum in the New World}

It may be assumed that E. ruminantium spread throughout sub-Saharan Africa, from its original area of evolution in southern Africa, primarily as a result of the movement of ruminant hosts together with their ticks. This is certainly the mechanism by which heartwater and the African bont tick $A$. variegatum were introduced to the Caribbean, either around 1830 (Curasson, 1943), or even possibly as early as the $18^{\text {th }}$ century (Maillard and Maillard, 1998). Up until 1948 the tick was only found in Guadeloupe and the neighbouring islands of Marie Galante and Antigua, inter-island trade in domestic stock took it to Martinique in 1948 (Uilenberg, 1990) but then, between 1967 and 1988, fourteen new islands were colonised by the tick (Barré et al., 1995). This sudden spread, which cannot be explained solely by livestock movements, coincides with the establishment of the African cattle egret (Bubulcus ibis) in the Caribbean (Barré et al., 1995). These birds are commonly infested with $A$. variegatum larvae, they also carry small numbers of nymphs, and they migrate widely between the Caribbean islands and even as far as the mainland (Barré et al., 1988; Corn et al., 1993). Cattle egrets are 
therefore likely to be important agents for disseminating the tick, in Africa as well as in the Caribbean.

It is notable that, although 14 new islands were colonised by $A$. variegatum between 1967 and 1988, heartwater remained confined to the three originally $A$. variegatum-infested islands, which suggests that the dissemination of E. ruminantiuminfected nymphs is very rare. Despite this, cattle egrets are known to migrate long distances and are well established in both north and south America (Telfair, 1994) so the possibility that egrets could transfer heartwater-infected $A$. variegatum nymphs from the Lesser Antilles to the American mainland certainly exists. Given that large areas of north, central and south America are climatically suitable for $A$. variegatum, and given that $A$. maculatum and the white tailed deer already constitute a viable native sylvatic tick-host pair for the maintenance of E. ruminantium, the establishment of endemic heartwater in the Americas will remain a potential economic threat until a safe and effective vaccine becomes available.

\section{Genetic variability}

There is no reliable vaccine for heartwater and over the last 60 years a great deal of research has been devoted towards remedying this situation. The biological variability among strains of the organism is obviously of great practical importance for vaccine development, so it is surprising that for much of the $20^{\text {th }}$ century it was thought that E. ruminantium was a relatively homogeneous organism. Only relatively recently, with the introduction of molecular genetic methods for characterization, has it become evident that it is, in fact, an extremely diverse organism, to the extent that it now appears to be adapting to canine (Allsopp and Allsopp, 2001) and human (Allsopp et al., 2005) hosts. Even more crucial for diversity is the discovery that extensive recombination occurs naturally between different genotypes of E. ruminantium (Allsopp and Allsopp, 2007) suggesting that newly generated strains are continuously arising in the field. We will consider some of the important pathogenic characteristics of the organism, which differ considerably from genotype to genotype, and which are of great significance for animal, and perhaps also human, health. 


\section{Ribosomal RNA genotypes}

Because of the significant variations observed in the biological characteristics of the organism it is important to try and establish what we mean by E. ruminantium. There is no universally accepted definition of what constitutes a prokaryotic species but some empirical guidelines have been used (Cohan, 2002). At one time a whole-genome hybridization level of $\geq 70 \%$ (Wayne et al., 1987), or a small subunit (16S) ribosomal RNA (srRNA) gene sequence identity level of $\geq 97 \%$, (Stackebrandt and Goebel, 1994), have been accepted to demarcate what was traditionally called a bacterial species. The recent determination of average nucleotide identity (ANI) between wholly sequenced prokaryote genomes indicates that a 70\% DNA-DNA reassociation level corresponds, on average, to $93-94 \% \mathrm{NAI}$ and to a srRNA gene sequence identity of $99 \%$ (Konstantinidis and Tiedje, 2005). The authors of this study suggest more stringent criteria for defining a prokaryotic species, at $94-99 \% \mathrm{ANI}$, corresponding to $99.0-99.9 \%$ srRNA identity.

The srRNA gene has been very widely used as a taxonomic and phylogenetic tool for classifying bacteria (Olsen and Woese, 1993) and currently eight different srRNA genotypes of $E$. ruminantium are known, each having a sequence identity of $>99.4 \%$ with respect to the others. These eight genotypes are all therefore quite definitely E. ruminantium by the latest srRNA identity criteria and Table 2 summarises important reference data for them. Note that one of them (Pretoria North) has not been isolated in tissue culture. An alignment of these eight E. ruminantium srRNA sequences, together with orthologs from six other Ehrlichia spp. and one from Anaplasma marginale, was used to infer a maximum likelihood tree using the PHYML program (Guindon and Gascuel, 2003). The result (Figure 2) shows that the E. ruminantium sequences form a tight cluster, well distinguished from the other Ehrlichia spp. with the exception of the recently discovered Ehrlichia species from Panola Mountain, Georgia, USA (Loftis et al., 2006). The srRNA sequence of this organism is $>99.2 \%$ identical with each of the other E. ruminantium sequences, so there is some justification for considering that this may be considered to be a strain of $E$. ruminantium. The organism has not, however, been shown to produce clinical heartwater.

We will discuss some of the biological differences between the eight E. ruminantium srRNA genotypes (Table 2), the Panola mountain Ehrlichia species, and 
the mixed stock known as the Kümm isolate (Du Plessis and Kumm, 1971). We will see that the biological characteristics of different isolates of E. ruminantium are very variable, both between different srRNA genotypes and also within a single srRNA genotype. Several workers have also shown that there are considerable sequence polymorphisms of various E. ruminantium genes and genetic regions both within and between srRNA genotypes (Allsopp et al., 2001; Allsopp et al., 2003; Van Heerden et al., 2004b).

\section{Infectivity and Pathogenicity}

When considering the early work done on the infectivity and pathogenicity of E. ruminantium it should be remembered that before the organism could be grown in vitro there were no methods for quantifying the infective dose. Genotyping methods had also not been developed, so there is no guarantee that individual genotypes of E. ruminantium were being used, nor that adequately infective challenge doses were being administered, nor even that the organisms could reliably be classified as E. ruminantium.

Infectivity to mice was the earliest method used to demonstrate variability between stocks and three different types of pathogenicity are recorded: pathogenic genotypes which can kill mice, genotypes which infect mice but are not pathogenic, and noninfective genotypes which fail to establish any infection in mice (Table 2). The Welgevonden genotype, for example, is always fatal for mice, whereas the Senegal genotype is only pathogenic if a large infective dose is given. The Ball 3 genotype infects mice subclinically, but it cannot be sub-passaged and the mice do not become long term carriers, while the Gardel genotype does not infect mice at all.

The Omatjenne genotype was first isolated by infecting a mouse with homogenate prepared from a single Hyalomma truncatum tick taken off a healthy cow on a farm in Namibia (Du Plessis, 1990). Eighty one percent of the cattle on this farm, despite being perfectly healthy, tested seropositive for heartwater using an immunofluorescent antibody test (Du Plessis and Malan, 1987a). There is no clinical heartwater in the area, nor any Amblyomma tick species known to transmit heartwater, but it is most likely that exposure to infection with the Omatjenne srRNA E. ruminantium genotype was the cause of the seropositive reactions in cattle. The same srRNA genotype was detected, by PCR and probing, in 70 healthy boergoats in a heartwater-free area of the Northern Cape in South Africa (Allsopp et al., 1997) which suggests that the Omatjenne genotype 
is also apathogenic to small ruminants. Despite the original isolation of the Omatjenne genotype being made from a Hyalomma truncatum tick this species is unlikely to be the primary vector of the organism, since the larvae and nymphs feed exclusively on scrub hares (Lepus saxatilis) and rodents, while only the adults feed on cattle (Allsopp et al., 2007). The Northern Cape study also showed the presence of other apparently nonpathogenic strains of $E$. ruminantium, with the detection of srRNA sequences identical to those of both non-pathogenic and virulent stocks of E. ruminantium (Allsopp et al., 2007). No known species of tick vector exist in this area, and the ticks responsible for transmitting the non-pathogenic organisms have not been identified. It has also not yet been possible to establish the organisms in tissue culture, which is an essential prerequisite if they are to be effectively characterized.

The Panola Mountain Ehrlichia species included in the Ehrlichia phylogenetic tree (Figure 2) was originally identified in A. americanum ticks from Panola Mountain State Park in Georgia, U.S.A. The DNA sequences of several genes (16S rRNA, gltA, map1, map1-1 and map2) have demonstrated that it is closely related to other E. ruminantium genotypes (Loftis et al., 2006) but it has not been shown to produce clinical heartwater. The organism does, however, produce a mild febrile illness in goats (Loftis et al., 2008a) and in humans (Reeves et al., 2008), and its natural reservoir may be the widely distributed white-tailed deer (Odocoileus virginanus) (Yabsley et al., 2008). Subsequent to its first detection the Panola Mountain Ehrlichia organism has been found in A. americanum ticks in 10 states in the U.S.A. (Loftis et al., 2008b) and the presence of genetic variations between isolates from different locations suggests that the organism is not a recent introduction into the United States. In view of its wide distribution it is probable that if this Ehrlichia species could cause a virulent clinical disease similar to heartwater then this would be well known, so it is likely that it does not represent a heartwater threat. The observation that $A$. americanum ticks cannot transmit some heartwater-producing strains of E. ruminantium of African and Caribbean origin (Uilenberg, 1982; Uilenberg et al., 1985) could be important in this context.

The Ball 3 genotype of $E$. ruminantium is used as an infection and treatment heartwater 'vaccine' in South Africa (Van der Merwe, 1987), and the main reason for choosing this genotype is that it produces an early-warning temperature rise. It differs in this respect from the highly virulent Welgevonden isolate which often causes death 
very shortly after a rapid temperature rise and is therefore not suitable for use in infection and treatment. We will discuss below an unfortunate disadvantage of the Ball 3 'vaccine', which is that it confers only limited protection against virulent field challenge with common genotypes like Welgevonden (Du Plessis et al., 1989).

Infectivity is not solely a property of the challenging E. ruminantium genotype but also depends on the tick vector, as discussed under "Transmission effectiveness" above. It is for this reason that the only technique which has been developed to deliver a quantitative challenge, which uses infected blood (Brayton et al., 2003), is not a good model for the challenge presented in the field by infected ticks. This will be discussed in more detail under "Vaccine development" below.

\section{Heterogeneous isolates}

The Kümm isolate was made from a goat in the heartwater endemic Northern Province of South Africa which was clinically diagnosed as having heartwater (Du Plessis and Kumm, 1971). A lymph node suspension from the animal caused what appeared to be heartwater in sheep, but the isolate was found to behave anomalously in mice and cattle and it was at one time doubted that it was E. ruminantium (Du Plessis, 1982). While apparently non-pathogenic for cattle the isolate was virulent in mice, and was unusual in that it infected mouse macrophages. It was for this reason used to prepare antigen slides for heartwater serology (Du Plessis et al., 1993) and was subsequently passaged more than 100 times, mainly in mice but also in sheep. The stock resisted all attempts to culture it for over 15 years, and it was only established in culture in 2002 (Zweygarth et al., 2002). It was found that the stock contained two different genotypes, designated Kümm 1 and Kümm 2, each having a distinct behaviour in culture (Table 3). Kümm 1 had the Senegal srRNA genotype and Kümm 2 the Omatjenne srRNA genotype. Kümm 2, however, did not behave identically to Omatjenne, the former being lethal in mice while the latter is not, and the former growing readily in sheep mononuclear cells while the latter did not.

\section{Immunogenicity}

The existence of immunogenetic variants within E. ruminantium, now known to be extensive, is also of crucial importance for the development of vaccines. We mentioned above that the Ball 3 infection and treatment 'vaccine' gives only limited protection against the Welgevonden genotype, but the virulence of the latter precludes its use for 
infection and treatment. For the purpose of vaccine development it is important to find genotypes which can confer cross-immunity to as wide a range of others as possible, but there are several practical difficulties in this search. Reliable cross-immunity trials depend upon having quantified challenge material, and on the availability of in vitro cultures of molecularly characterized single genotypes, and it is only within the last few years that these constituents have been developed (Brayton et al., 2003; Zweygarth and Josemans, 2001). One experiment using carefully controlled material has been carried out in sheep using four different E. ruminantium srRNA genotypes (Ball 3, Mara 87/7, Gardel, Welgevonden) and two other isolates (Kwanyanga and Blaauwkrans, both of Welgevonden srRNA genotype) (Collins et al., 2003). The animals were infected, treated when they became febrile, and a homologous challenge was performed to determine their immune status. They were then subjected to a heterologous challenge and it was found that the Welgevonden genotype was the only one which provided complete cross-protection against challenge with any of the other stocks. The Kwanyanga, Gardel and Blaauwkrans stocks provided little cross-protection against heterologous challenge, while Mara 87/7 and Ball 3 provided limited cross-protection against heterologous challenge. It is notable that, among the stocks having the Welgevonden srRNA genotype, Welgevonden protected against Kwanyanga and Blaauwkrans, but not vice-versa.

\section{Emergence of novel phenotypes}

The development of the pCS20 assay for E. ruminantium detection (Mahan et al., 1992; Van Heerden et al., 2004b) has revealed the presence of the organism in a number of atypical or unexplained infections occurring after tick bite in both nonruminants and humans. Canine ehrlichiosis is commonly encountered in S. Africa and is normally diagnosed on the basis of clinical symptoms and blood smear examination. Some animals, however, show symptoms suggestive of canine ehrlichiosis but without morulae being seen on blood smears, and these are often tested using a PCR assay specific for North American Ehrlichia canis (McBride et al., 1996). Most of these cases are negative for $E$. canis, but many of them test positive for $E$. ruminantium by the pCS20 assay (Allsopp and Allsopp, 2001). In one of these E. canis-negative E. ruminantium-positive cases other $E$. ruminantium-specific gene sequences were 
obtained, strongly suggesting that an E. ruminantium variant contributed to the animal's illness (Allsopp and Allsopp, 2001).

Recently E. ruminantium has also been detected in DNA from three human serum samples using the pCS20 assay. All three individuals died, and other E. ruminantiumspecific gene sequences were also found in the samples, suggesting that E. ruminantium variants can cause a lethal infection in humans (Allsopp et al., 2005).

\section{Diagnostics}

The clinical diagnosis of heartwater in live animals has been fraught with difficulty until quite recently (Camus and Barré, 1987). Many of the traditional symptoms associated with the disease are not pathognomic, and a definitive diagnosis of heartwater usually had to await post mortem examination. Even then it was not always simple, since the pathology of the disease varies from one host species to another, and many other infectious and non-infectious conditions exhibit signs which mimic heartwater (Prozesky, 1987b). Ultimately reliance was often placed on the demonstration of E. ruminantium in the cytoplasm of endothelial cells of brain capillaries (Purchase, 1945), where colonies of the organism are generally more numerous than in other tissues. While the characteristic colonies of E. ruminantium are easy to detect, if present in sufficient numbers, it is not possible to distinguish them from other species of Ehrlichia, and they may also be confused with Chlamydia psittaci.

\section{Serology}

The first serological test developed for E. ruminantium was an indirect fluorescent antibody test (IFAT) which used peritoneal macrophages from mice infected with the Kümm stock as the target antigen (Du Plessis and Malan, 1987a). We have described above how this stock was subsequently found to contain two different srRNA genotypes, designated Kümm 1 and Kümm 2, each having a distinct behaviour in culture (Table 3). It is perhaps not surprising, then, that this test suffered from cross-reactions with antibodies against related Ehrlichia spp., resulting in the common occurrence of false positive results (Du Plessis and Malan, 1987c; Holland et al., 1987).

Several other serological tests were developed over a period of years, detecting antibodies to the immunodominant E. ruminantium outer membrane protein MAP1, but they all suffered from the detection of false positives and false negatives. We now know 
that the reason for these problems is the existence of homologous families of immunodominant outer membrane proteins in several Ehrlichia and Anaplasma spp. (Ohashi et al., 2001; Palmer et al., 1994; Van Heerden et al., 2004a; Yu et al., 2000). The best serological test for E. ruminantium uses a recombinant fragment of MAP1, designated MAP 1B, in an indirect ELISA format (van Vliet et al., 1995), but even this test detects antibodies to E. canis, E. chaffeensis, and an unidentified Ehrlichia sp. infecting white-tailed deer (Odocoileus virginianus) in the south eastern United States (Katz et al., 1996). An additional problem affecting all serological tests for heartwater in cattle is that antibody levels against $E$. ruminantium are often too low to be detected, even in animals that have been vaccinated or are under continuous natural challenge by infected ticks (De Waal et al., 2000; Semu et al., 2001).

\section{Molecular genetic methods}

The PCR-based molecular genetic revolution in diagnostic techniques has provided the only reliable methods for $E$. ruminantium diagnosis. Three families of probes have been used, targeting the pCS20 genetic region, the srRNA gene, and the map1 gene. The pCS20 genetic region was the first genetic target to be identified especially for E. ruminantium diagnosis (Waghela et al., 1991) and it has proved to be specific for E. ruminantium, giving no cross reactions with other Ehrlichia species (Allsopp et al., 1999). It is the most sensitive of the probes available for E. ruminantium detection and has been extensively used to detect the organism in domestic animals, wild game, and ticks (Allsopp et al., 1999; Mahan et al., 1998; Mahan et al., 1992; Peter et al., 1999; Peter et al., 1995) (Mahan et al., 2004; Peter et al., 2000; Simbi et al., 2003).

The original 1,306 bp pCS20 plasmid clone (Waghela et al., 1991) has been found to be chimaeric (Van Heerden et al., 2004b) and a redesign of primers and probes for the diagnostic test has resulted in improved sensitivity (Van Heerden et al., 2004b). The test will detect down to a single copy of the target gene, and there is a minor cross reaction with $E$. chaffeensis DNA at a 10x greater concentration. The pCS20 test has recently been adapted to a quantitative real-time PCR format (Steyn et al., 2008), and in this format it cross-reacts with both E. chaffeensis and E. canis. The pCS20 region has been shown by many workers over several years to provide a specific test for E. ruminantium. Even so there are sequence polymorphisms in the pCS20 region, although most of them are single nucleotide differences. The sequences of the pCS20 
region of 14 different $E$. ruminantium isolates shows that West African isolates are more highly conserved than are southern African isolates (Van Heerden et al., 2004b).

We have already mentioned the existence of eight different srRNA genotypes of E. ruminantium and srRNA probes have been used in field surveys (Allsopp et al. , 1998). The srRNA probes are difficult to use, because the sequence variations are small, and they do not provide such sensitive detection as the pCS20 probe, so they are not used for routine diagnosis. They are particularly useful, however, when previously unknown Ehrlichia spp. are encountered, allowing them to be phylogenetically identified as E. ruminantium or else to be assigned to other groupings. These probes are also used, together with the pCS20 probe, on animals which are being examined to obtain permits for importation into non heartwater endemic areas. The map1 gene, which is extensively polymorphic, has also been used as a diagnostic target for E. ruminantium in order to characterise different antigenic variants of the parasite (Allsopp et al., 2001).

\section{Vaccine development}

The only commercially available procedure for heartwater immunisation is a 50 year old infection and treatment technique which is described in more detail under "Control" below. The method has a number of serious drawbacks (Van der Merwe, 1987) and there has been a great deal of research over the last two decades aimed at producing a more effective vaccine. Three different types of vaccine have been investigated, inactivated, attenuated, and recombinant, and we will briefly consider the latest developments for each type.

\section{Inactivated vaccines}

Inactivated heartwater vaccines consist of organisms derived from tissue culture which have been rendered non-viable by chemical treatment. The first successful application of such material was in goats using the Gardel isolate, and $50-80 \%$ of the animals were protected against a homologous needle challenge which killed $100 \%$ of the negative controls (Martinez et al., 1994). The next report used the Crystal Springs isolate in sheep, and in this case $50-100 \%$ of the animals were protected against a homologous needle challenge which killed $60 \%$ of the negative controls (Mahan et al., 1995). These early successes were unfortunately not repeated when trials were conducted in a field situation, where natural tick challenge with genotypes having differing immunogenicities would have occurred. Several reports indicate that under 
these circumstances the vaccine reduces mortality levels, but protection levels have been disappointing (Faburay et al., 2007; Mahan et al., 2001). A summary of all the field trials conducted by one research group over a period of years shows that overall mortality levels of $71 \%$ in naive animals can be reduced to $36 \%$ by vaccination (Mahan et al., 2003).

The high cost of batch culture systems for $E$. ruminantium is a factor which has long been an obstacle to its development for large scale use in the field (Esteves et al., 2004). Recently, however, there have been notable improvements in mass production of the organism which could make commercial scale preparation feasible (Marcelino et al., 2006). There still remains the problem of limited protection against tick challenge in the field, and it is likely that considerable improvements in this regard will be required before inactivated heartwater vaccines could become a commercially viable proposition.

\section{Attenuated vaccines}

The Senegal isolate of $E$. ruminantium was the first isolate to be attenuated in culture, and it conferred $100 \%$ protection on animals subjected to a homologous needle challenge (Jongejan, 1991). As with the inactivated vaccine, however, the results were far less satisfactory when field trials were conducted, with $70 \%$ mortality in the negative controls being reduced to $43 \%$ in the vaccinated animals (Gueye et al., 1994). The Welgevonden isolate has been shown, as discussed above, to provide cross-protection against a needle challenge with a range of other isolates (Collins et al., 2003). This could make the Welgevonden isolate a good candidate to use as an attenuated vaccine, but unfortunately it did not attenuate while being grown in culture through hundreds of passages over several years (Gueye et al., 1994; Zweygarth et al., 1997). Recently, however, the Welgevonden isolate was attenuated by being cultured in a canine macrophage-monocyte cell line, after which it was by re-adapted to grow in bovine endothelial cells (Zweygarth et al., 2005). When the attenuated organisms were used to infect sheep or goats there were no adverse symptoms, except for a brief rise in body temperature, and the animals were subsequently found to be fully protected against a lethal needle challenge with the homologous isolate or any one of four other heterologous isolates (Zweygarth et al., 2005). This attenuated vaccine has not yet been tested in the field against natural tick challenge, but if it were to be successful in 
such trials it could provide a cheap and effective vaccine for use in endemic heartwater areas.

\section{Recombinant vaccines}

The fact that immunization with killed organisms can be successful indicates that the development of a subunit vaccine for E. ruminantium is possible. Such a vaccine could in principle be cheap and effective, and unlike the attenuated vaccine it could be used to stop an outbreak in a non-endemic area. The first attempts to develop a recombinant vaccine involved immunisation with a plasmid clone expressing the map1 gene of E. ruminantium, and this protected mice against a lethal homologous challenge at levels ranging from $23 \%$ to $88 \%$ (Nyika et al., 1998). In further experiments the naked DNA-induced immunity was boosted with MAP1 protein and as a result protection levels were increased from a range of $13-27 \%$ without boosting to a range of $53-67 \%$ (Nyika et al., 2002).

Denatured MAP1 protein appears to confer no protection in ruminants (Van Kleef et al., 1993), so the map1 gene might not be the best choice for recombinant vaccine experiments. The recent completion of the genome sequence of E. ruminantium shows that there are 888 genes from which to chose vaccine candidates (Collins et al., 2005) but the problem is that there are no reliable strategies for identifying the genes which code for antigens which stimulate the protective T-cell response (Esteves et al., 2004). One attempt to overcome this difficulty involved selecting clones from E. ruminantium expression libraries on the basis that their expression products were firstly recognized by anti-E. ruminantium antibodies, and secondly that they stimulated proliferation of PBMC from cattle immunised against E. ruminantium by infection and treatment (Barbet et al., 2001). Lysates of recombinant bacterial cultures expressing the selected genes were then used to immunize mice, and $58 \%$ - $89 \%$ survival was observed with some pools of recombinants. The levels of protection were therefore similar to those obtained with the map1 gene.

E. ruminantium immunization trials performed in mice have given unpredictably variable results, and genes which have conferred immunity in such trials have often not been protective in ruminants (Collins et al., 2003; Louw et al., 2002). Vaccination trials conducted in sheep, however, have been shown to be reproducible. A cocktail of four E. ruminantium genes cloned in a DNA vaccine vector consistently stimulated $100 \%$ 
protection in sheep against a virulent needle challenge with both homologous and heterologous E. ruminantium-infected blood (Collins et al., 2003; Pretorius et al., 2007). In trials against a natural tick challenge in the field this vaccine was poorly protective, even when used in a prime-boost format with recombinant E. ruminantium proteins (Pretorius et al., 2008), and several possible reasons for this have been discussed in the Tick-Host-Pathogen Interface section above.

\section{Future Research}

There is no doubt that heartwater is of major economic importance in domestic ruminants throughout sub-Saharan Africa, and an efficient vaccine is the only costeffective method by which control may be achieved. While an attenuated vaccine may become useful in the endemic area in Africa it is likely that a recombinant vaccine will be the best long-term solution, especially in the event that the disease spreads to the American mainland. Future research should therefore have vaccine development as its main goal, but there are several fundamental aspects of the biology of E. ruminantium which are poorly understood and which need clarification in order to support vaccine development. We will list some of the principal questions. A) What is the nature and location of the genetic and phenotypic changes which occur during the developmental cycle in the tick? B) What is the role of the tick in enhancing the potency of infecting elementary bodies? C) What are the molecular mechanisms which allow persistent infections of natural mammalian hosts? D) What is the nature and control of those E. ruminantium virulence factors which control the pathogenesis of the disease in ruminants? E) Which E. ruminantium proteins are crucial to stimulating protective immunity, and what is the nature of the protective immune mechanisms. There are partial answers to some of these questions, but others are almost completely unanswered.

The recent publication of the genome sequences of several important rickettsial pathogens, including E. ruminantium, could provide the starting point for the development of functional genomic studies to enlighten some of the murky areas of E. ruminantium biology. A rapidly growing range of mostly high throughput screening methods is beginning to be able to determine the functions of individual genes and proteins in a global context, rather than one gene product at a time. In the case of E. ruminantium the 
global context includes the tick and the ruminant, which indicates that comprehensive answers to some of the questions above will not become available until genome sequences are available for these other two essential players in the parasitic cycle. The current frontier of E. ruminantium research is to look for vaccine candidate genes, but the algorithms used to predict these candidates are all narrowly focussed on single genes of the rickettsia itself. We are unlikely to be able to make good predictions until we know how all the genes and their products interact within the tick-host-pathogen triad. Answering these complex questions will require the application of the resources of functional genomics, proteomics, transcriptome characterization, and genetic manipulation. 


\section{References}

Allsopp, M.T., Allsopp, B.A., 2001. Novel Ehrlichia genotype detected in dogs in South Africa. J Clin Microbiol 39, 4204-4207.

Allsopp, M.T., Allsopp, B.A., 2007. Extensive genetic recombination occurs in the field between different genotypes of Ehrlichia ruminantium. Vet Microbiol 124, 58-65.

Allsopp, M.T., Dorfling, C.M., Maillard, J.C., Bensaid, A., Haydon, D.T., van Heerden, H., Allsopp, B.A., 2001. Ehrlichia ruminantium major antigenic protein gene (map1) variants are not geographically constrained and show no evidence of having evolved under positive selection pressure. J Clin Microbiol 39, 4200-4203.

Allsopp, M.T., Hattingh, C.M., Vogel, S.W., Allsopp, B.A., 1998. Comparative evaluation of 16S, map1 and pCS20 probes for the detection of Cowdria and Ehrlichia species in ticks. Ann N Y Acad Sci 849, 78-84.

Allsopp, M.T., Hattingh, C.M., Vogel, S.W., Allsopp, B.A., 1999. Evaluation of 16S, map1 and pCS20 probes for detection of Cowdria and Ehrlichia species. Epidemiol Infect 122, 323-328.

Allsopp, M.T., Louw, M., Meyer, E.C., 2005. Ehrlichia ruminantium: An emerging human pathogen? Ann N Y Acad Sci 1063, 358-360.

Allsopp, M.T., Theron, J., Coetzee, M.L., Dunsterville, M.T., Allsopp, B.A., 1999. The occurrence of Theileria and Cowdria parasites in African buffalo (Syncerus caffer) and their associated Amblyomma hebraeum ticks. Onderstepoort J Vet Res 66, 245-249.

Allsopp, M.T., Van Heerden, H., Steyn, H.C., Allsopp, B.A., 2003. Phylogenetic relationships among Ehrlichia ruminantium isolates. Ann N Y Acad Sci 990, 685-691.

Allsopp, M.T., Van Strijp, M.F., Faber, E., Josemans, A.I., Allsopp, B.A., 2007. Ehrlichia ruminantium variants which do not cause heartwater found in South Africa. Vet Microbiol 120, 158-166 . 
Allsopp, M.T., Visser, E.S., du Plessis, J.L., Vogel, S.W., Allsopp, B.A., 1997. Different organisms associated with heartwater as shown by analysis of $16 S$ ribosomal RNA gene sequences. Vet Parasitol 71, 283-300.

Andrew, H.R., Norval, R.A., 1989a. The carrier status of sheep, cattle and African buffalo recovered from heartwater. Vet Parasitol 34, 261-266.

Andrew, H.R., Norval, R.A.I., 1989b. The role of males of the bont tick (Amblyomma hebraeum) in the transmission of Cowdria ruminantium (heartwater). Vet Parasitol 34, 15-23.

Barbet, A.F., Whitmire, W.M., Kamper, S.M., Simbi, B.H., Ganta, R.R., Moreland, A.L., Mwangi, D.M., McGuire, T.C., Mahan, S.M., 2001. A subset of Cowdria ruminantium genes important for immune recognition and protection. Gene 275, 287-298.

Barré, N., Garris, G., Camus, E., 1995. Propagation of the tick Amblyomma variegatum in the Caribbean. Rev Sci Tech 14, 841-855.

Barré, N., Garris, G.I., Borel, G., Camus, E., 1988. Hosts and population dynamics of Amblyomma variegatum (Acari: Ixodidae) on Guadeloupe, French West Indies. J Med Entomol. 25, 111-115.

Beveridge, T.J., Davies, J.A., 1983. Cellular responses of Bacillus subtilis and Escherichia coli to the Gram stain. J Bacteriol 156, 846-858.

Bezuidenhout, J.D., 1987 . Natural transmission of heartwater. Onderstepoort J Vet Res 54, 349-351.

Bezuidenhout, J D, 1988. Certain aspects of the transmission of heartwater, the occurrence of the organism in ticks and in vitro culture. D.V.Sc. Thesis, University of Pretoria, South Africa.

Brayton, K.A., Collins, N.E., van Strijp, F., Allsopp, B.A., 2003. Preparation of Ehrlichia ruminantium challenge material for quantifiable and reproducible challenge in mice and sheep. Vet Parasitol 112, 63-73. 
Camus, E, 1987. Contribution à l'étude épidémiologique de la cowdriose ( $C$. ruminantium) en Guadeloupe. D.-es-Sc. Thesis, Université de Paris-Sud, Paris.

Camus, E., 1992. Le portage asymptomatique de bovins et chèvres Créole guéris de la cowdriose en Guadeloupe. Rev Elev Med Vet Pays Trop 45, 133-135.

Camus, E., Barré, N., 1987. Diagnosis of heartwater in the live animal: experiences with goats in Guadeloupe. Onderstepoort J Vet Res 54, 291-294.

Camus, E., Barré, N., 1992. The role of Amblyomma variegatum in the transmission of heartwater with special reference to Guadeloupe. Ann N Y Acad Sci 653, 33-41.

Cohan, F.M., 2002. What are bacterial species? Annu Rev Microbiol 56, 457-487.

Collins, N.E., Liebenberg, J., de Villiers, E.P. , Brayton, K.A., Louw, E., Pretorius, A., Faber, F.E., van Heerden, H., Josemans, A., van Kleef, M., Steyn, H.C., van Strijp, M.F., Zweygarth, E., Jongejan, F., Maillard, J.C., Berthier, D., Botha, M., Joubert, F., Corton, C.H., Thomson, N.R., Allsopp, M.T., Allsopp, B.A., 2005. The genome of the heartwater agent Ehrlichia ruminantium contains multiple tandem repeats of actively variable copy number. Proc Natl Acad Sci U S A 102, 838-843.

Collins, N.E., Pretorius, A., van Kleef, M., Brayton, K.A., Allsopp, M.T., Zweygarth, E., Allsopp, B.A., 2003. Development of improved attenuated and nucleic acid vaccines for heartwater. Dev Biol (Basel) 114, 121-136.

Corn, J.L., Barré, N., Thiebot, B., Creekmore, T.E., Garris, G.I., Nettles, V.F., 1993. Potential role of cattle egrets, Bubulcus ibis (Ciconiformes: Ardeidae), in the dissemination of Amblyomma variegatum (Acari: Ixodidae) in the eastern Caribbean. $\mathrm{J}$ Med Entomol. 30, 1029-1037.

Cowdry, E.V., 1925a. Studies on the etiology of heartwater 1. Observation of a rickettsia, Rickettsia ruminantium (n. sp.), in the tissues of infected animals. J Exp Med 42, 231252.

Cowdry, E.V., 1925b. Studies on the etiology of heartwater 2. Rickettsia ruminantium (n. sp.) in the tissues of ticks transmitting the disease. J Exp Med 42, 253-274. 
Curasson, G. Traité de Pathologie Vétérinaire et Comparée: Tome 1 - Trypanosomes. 1, p. 272. 43. Paris, Vigot Frères, Éditeurs.

De Waal, D.T., Matthee, O., Jongejan, F., 2000. Evaluation of the MAP1b ELISA for the diagnosis of heartwater in South Africa. Ann N Y Acad Sci 916, 622-627.

Deem, S.L., 1998. A review of heartwater and the threat of introduction of Cowdria ruminantium and Amblyomma spp. ticks to the American mainland. J Zoo WildI Med 29, 109-113.

Deem, S.L., Norval, R.A., Donachie, P.L., Mahan, S.M., 1996. Demonstration of vertical transmission of Cowdria ruminantium, the causative agent of heartwater, from cows to their calves. Vet Parasitol 61, 119-132.

Du Plessis, J.L., 1970. Pathogenesis of heartwater. I. Cowdria ruminantium in the lymph nodes of domestic ruminants. Onderstepoort J Vet Res 37, 89-95.

Du Plessis, J L, 1982. Mice infected with a Cowdria ruminantium-like agent as a model in the study of heartwater. D.V.Sc. Thesis, University of Pretoria, South Africa.

Du Plessis, J.L., 1985. A method for determining the Cowdria ruminantium infection rate of Amblyomma hebraeum: effects in mice injected with tick homogenates. Onderstepoort J Vet Res 52, 55-61.

Du Plessis, J.L., 1990. Increased pathogenicity of an Ehrlichia-like agent after passage through Amblyomma hebraeum: a preliminary report. Onderstepoort J Vet Res 57, 233237.

Du Plessis, J.L., Bezuidenhout, J.D., Brett, M.S., Camus, E., Jongejan, F., Mahan, S.M., Martinez, D., 1993. The sero-diagnosis of heartwater: a comparison of five tests. Rev Elev Med Vet Pays Trop 46, 123-129.

Du Plessis, J.L., Kumm, N.A., 1971. The passage of Cowdria ruminantium in mice. J S Afr Vet Med Assoc 42, 217-221.

Du Plessis, J.L., Malan, L., 1987a. The application of the indirect fluorescent antibody test in research on heartwater. Onderstepoort J Vet Res 54, 319-325. 
Du Plessis, J.L., Malan, L., 1987b. The non-specific resistance of cattle to heartwater. Onderstepoort J Vet Res 54, 333-336.

Du Plessis, J.L., Malan, L., 1987c. Problems with the interpretation of epidemiological data in heartwater: a study on 23 farms. Onderstepoort J Vet Res 54, 427-433.

Du Plessis, J.L., Van Gas, L., Olivier, J.A., Bezuidenhout, J.D., 1989 . The heterogenicity of Cowdria ruminantium stocks: cross-immunity and serology in sheep and pathogenicity to mice. Onderstepoort J Vet Res 56, 195-201.

Dumler, J.S., Barbet, A.F., Bekker, C.P., Dasch, G.A., Palmer, G.H., Ray, S.C., Rikihisa, Y., Rurangirwa, F.R., 2001. Reorganization of genera in the families Rickettsiaceae and Anaplasmataceae in the order Rickettsiales: unification of some species of Ehrlichia with Anaplasma, Cowdria with Ehrlichia and Ehrlichia with Neorickettsia, descriptions of six new species combinations and designation of Ehrlichia equi and 'HGE agent' as subjective synonyms of Ehrlichia phagocytophila. Int J Syst Evol Microbiol 51, 21452165.

Esteves, I., Vachiery, N., Martinez, D., Totte, P., 2004. Analysis of Ehrlichia ruminantium-specific T1/T2 responses during vaccination with a protective killed vaccine and challenge of goats. Parasite Immunol 26, 95-103.

Faburay, B., Geysen, D., Ceesay, A., Marcelino, I., Alves, P.M., Taoufik, A., Postigo, M., Bell-Sakyi, L., Jongejan, F., 2007. Immunisation of sheep against heartwater in The Gambia using inactivated and attenuated Ehrlichia ruminantium vaccines. Vaccine 25, 7939-7947.

Ferreira, B.R., Silva, J.S., 1998. Saliva of Rhipicephalus sanguineus tick impairs T cell proliferation and IFN-gamma-induced macrophage microbicidal activity. Vet Immunol Immunopathol 64, 279-293.

Gueye, A., Jongejan, F., Mbengue, M., Diouf, A., Uilenberg, G., 1994. Essai sur le terrain d'un vaccin atténué contre la cowdriose. Rev Elev Med Vet Pays Trop 47, 401404. 
Gueye, A., Mbengue, M., Diouf, A., 1993. Épidémiologie de la cowdriose au Sénégal. 1. Étude de la transmission et du taux d'infection d'Amblyomma variegatum (Fabricius, 1794) dans la région des Niayes. Rev Elev Med Vet Pays Trop 46, 441-447.

Guindon, S., Gascuel, O., 2003. A simple, fast, and accurate algorithm to estimate large phylogenies by maximum likelihood. Syst Biol 52, 696-704.

Haig, D.A., 1952. Note on the use of the white mouse for the transport of strains of heartwater. J S Afr Vet Med Assoc 23, 167-170.

Holland, C.J., Logan, L.L., Mebus, C.A., Ristic, M., 1987. The serological relationship between Cowdria ruminantium and certain members of the genus Ehrlichia. Onderstepoort J Vet Res 54, 331.

Howell, D.J., Petney, T.N., Horak, I.G., 1989. The host status of the striped mouse, Rhabdomys pumilio, in relation to the tick vectors of heartwater in South Africa. Onderstepoort J Vet Res 56, 289-291.

Hudson, J.R., Henderson, R.M., 1941. Some preliminary experiments on the survival of heartwater "virus" in rats. J S Afr Vet Med Assoc 12, 39-49.

Jongejan, F., 1991. Protective immunity to heartwater (Cowdria ruminantium infection) is acquired after vaccination with in vitro-attenuated rickettsiae. Infect Immun 59, 729731.

Jongejan, F., Uilenberg, G., Franssen, F.F., Gueye, A., Nieuwenhuijs, J., 1988. Antigenic differences between stocks of Cowdria ruminantium. Res Vet Sci 44, 186-189.

Jongejan, F., Zandbergen, T.A., van de Wiel, P.A., de Groot, M., Uilenberg, G., 1991. The tick-borne rickettsia Cowdria ruminantium has a Chlamydia-like developmental cycle. Onderstepoort J Vet Res 58, 227-237.

Katavolos, P., Armstrong, P.M., Dawson, J.E., Telford, S.R. 3rd, 1998. Duration of tick attachment required for transmission of granulocytic ehrlichiosis. J Infect Dis 177, 14221425. 
Katz, J.B., Barbet, A.F., Mahan, S.M., Kumbula, D., Lockhart, J.M., Keel, M.K., Dawson, J.E., Olson, J.G., Ewing, S.A., 1996. A recombinant antigen from the heartwater agent (Cowdria ruminatium) reactive with antibodies in some southeastern United States whitetailed deer (Odocoileus virginianus), but not cattle, sera. J Wildl Dis 32, 424-430.

Kocan, K.M., Bezuidenhout, J.D., Hart, A., 1987a. Ultrastructural features of Cowdria ruminantium in midgut epithelial cells and salivary glands of nymphal Amblyomma hebraeum. Onderstepoort J Vet Res 54, 87-92.

Kocan, K.M., Morzaria, S.P., Voigt, W.P., Kiarie, J., Irvin, A.D., 1987b. Demonstration of colonies of Cowdria ruminantium in midgut epithelial cells of Amblyomma variegatum. Am J Vet Res 48, 356-360.

Konstantinidis, K.T., Tiedje, J.M., 2005. Genomic insights that advance the species definition for prokaryotes. Proc Natl Acad Sci U S A. 102, 2567-2572.

Loftis, A.D., Levin, M.L., Spurlock, J.P., 2008a. Two USA Ehrlichia spp. cause febrile illness in goats. Vet Microbiol 130, 398-402.

Loftis, A.D., Mixson, T.R., Stromdahl, E.Y., Yabsley, M.J., Garrison, L.E., Williamson, P.C., Fitak, R.R., Fuerst, P.A., Kelly, D.J., Blount, K.W., 2008b. Geographic distribution and genetic diversity of the Ehrlichia sp. from Panola Mountain in Amblyomma americanum. BMC Infect Dis 8, 54.

Loftis, D.A., Reeves, W.K., Spurlock, J.P., Mahan, S.M., Troughton, D.R., Dasch, G.A., Levin, M.L., 2006. Infection of a goat with a tick-transmitted Ehrlichia from Georgia, U.S.A., that is closely related to Ehrlichia ruminantium. J Vector Ecol 31, 213-223.

Lounsbury, C.P., 1900. Tick heartwater experiments. Agricultural Journal of the Cape of Good Hope 16, 682-687.

Lounsbury, C.P., 1902. Heartwater in calves. Agricultural Journal of the Cape of Good Hope 21, 165-169. 
Louw, E., Brayton, K.A., Collins, N.E., Pretorius, A., Van Strijp, F., Allsopp, B.A., 2002. Sequencing of a 15-kb Ehrlichia ruminantium clone and evaluation of the cpg1 open reading frame for protection against heartwater. Ann N Y Acad Sci 969, 147-150.

MacKenzie, P.K., McHardy, N., 1987. Cowdria ruminantium infection in the mouse: a review. Onderstepoort J Vet Res 54, 267-269.

Mahan, S.M., Andrew, H.R., Tebele, N., Burridge, M.J., Barbet, A.F., 1995. Immunisation of sheep against heartwater with inactivated Cowdria ruminantium. Res Vet Sci 58, 46-49.

Mahan, S.M., Barbet, A.F., Burridge, M.J., 2003. Development of improved vaccines for heartwater. Dev Biol (Basel) 114, 137-145.

Mahan, S.M., Peter, T.F., Simbi, B.H., Burridge, M.J., 1998. PCR detection of Cowdria ruminantium infection in ticks and animals from heartwater-endemic regions of Zimbabwe. Ann N Y Acad Sci 849, 85-87.

Mahan, S.M., Peter, T.F., Simbi, B.H., Kocan, K., Camus, E., Barbet, A.F., Burridge, M.J., 2000. Comparison of efficacy of American and African Amblyomma ticks as vectors of heartwater (Cowdria ruminantium) infection by molecular analyses and transmission trials. J Parasitol 86, 44-49.

Mahan, S.M., Simbi, B.H., Burridge, M.J., 2004. The pCS20 PCR assay for Ehrlichia ruminantium does not cross-react with the novel deer ehrlichial agent found in whitetailed deer in the United States of America. Onderstepoort J Vet Res 71, 99-105.

Mahan, S.M., Smith, G.E., Kumbula, D., Burridge, M.J., Barbet, A.F., 2001. Reduction in mortality from heartwater in cattle, sheep and goats exposed to field challenge using an inactivated vaccine. Vet Parasitol 97, 295-308.

Mahan, S.M., Waghela, S.D., McGuire, T.C., Rurangirwa, F.R., Wassink, L.A., Barbet, A.F., 1992. A cloned DNA probe for Cowdria ruminantium hybridizes with eight heartwater strains and detects infected sheep. J Clin Microbiol 30, 981-986. 
Maillard, J.C., Maillard, N., 1998. Historique du peuplement bovin et de l'introduction de la tique Amblyomma variegatum dans les îles françaises des Antilles: Synthèse bibliographique. Ethnozootechnie 1, 19-36.

Marcelino, I., Sousa, M.F., Verissimo, C., Cunha, A.E., Carrondo, M.J., Alves, P.M., 2006. Process development for the mass production of Ehrlichia ruminantium. Vaccine. 24, 1716-1725. Epub 2005 Oct 14.

Martinez, D., Maillard, J.C., Coisne, S., Sheikboudou, C., Bensaid, A., 1994. Protection of goats against heartwater acquired by immunisation with inactivated elementary bodies of Cowdria ruminantium. Vet Immunol Immunopathol 41, 153-163.

McBride, J.W., Corstvet, R.E., Gaunt, S.D., Chinsangaram, J., Akita, G.Y., Osburn, B.I., 1996. PCR detection of acute Ehrlichia canis infection in dogs. J Vet Diagn Invest 8 , 441-447.

Molia, S., Frebling, M., Vachiery, N., Pinarello, V., Petitclerc, M., Rousteau, A., Martinez, D., Lefrancois, T., 2008. Amblyomma variegatum in cattle in Marie Galante, French Antilles: prevalence, control measures, and infection by Ehrlichia ruminantium. Vet Parasitol 153, 338-46.

Moshkovski, S.D., 1947. Comments by readers. Science 106, 62.

Mukhebi, A.W., Chamboko, T., O'Callaghan, C.J., Peter, T.F., Kruska, R.L., Medley, G.F., Mahan, S.M., Perry, B.D., 1999. An assessment of the economic impact of heartwater (Cowdria ruminantium infection) and its control in Zimbabwe. Prev Vet Med 39, 173-189.

Neitz, W.O., 1935. The blesbuck (Damaliscus albifrons) and the Black-Wilde Beest (Conochaetes gnu) as carriers of heartwater. Onderstepoort J Vet Sci Anim Ind 5, 3540.

Neitz, W.O., 1964. Tick-borne diseases as a hazard in the rearing of calves in Africa. Bull Off Int Épizoot 62, 607-625. 
Neitz, W.O., 1967. The epidemiological pattern of viral, protophytal and protozoal zoonoses in relation to game preservation in South Africa. J S Afr Vet Med Assoc 38, $129-141$.

Neitz, W.O., 1968. Heartwater. Bull Off Int Épizoot 70, 329-336 .

Nyika, A., Barbet, A.F., Burridge, M.J., Mahan, S.M., 2002. DNA vaccination with map1 gene followed by protein boost augments protection against challenge with Cowdria ruminantium, the agent of heartwater. Vaccine 20, 1215-1225.

Nyika, A., Mahan, S.M., Burridge, M.J., Mcguire, T.C., Rurangirwa, F., Barbet, A.F., 1998. A DNA vaccine protects mice against the rickettsial agent Cowdria ruminantium. Parasite Immunol 20, 111-119.

Oberem, P.T., Bezuidenhout, J.D., 1987. Heartwater in hosts other than domestic ruminants. Onderstepoort J Vet Res 54, 271-275.

Ohashi, N., Rikihisa, Y., Unver, A., 2001. Analysis of transcriptionally active gene clusters of major outer membrane protein multigene family in Ehrlichia canis and $E$. chaffeensis. Infect Immun 69, 2083-2091.

Olsen, G., Woese, C., 1993. Ribosomal RNA: a key to phylogeny. FASEB J. 7, 113-123.

Palmer, G.H., Eid, G., Barbet, A.F., McGuire, T.C., McElwain, T.F., 1994. The immunoprotective Anaplasma marginale major surface protein 2 is encoded by a polymorphic multigene family. Infect Immun 62, 3808-3816

Peter, T.F., Barbet, A.F., Alleman, A.R., Simbi, B.H., Burridge, M.J., Mahan, S.M., 2000. Detection of the agent of heartwater, Cowdria ruminantium, in Amblyomma ticks by PCR: validation and application of the assay to field ticks. J Clin Microbiol 38, 15391544.

Peter, T.F., Bryson, N.R., Perry, B.D., O'Callaghan, C.J., Medley, G.F., Smith, G.E., Mlambo, G., Horak, I.G., Burridge, M.J., Mahan, S.M., 1999. Cowdria ruminantium infection in ticks in the Kruger National Park. Vet Rec 145, 304-307. 
Peter, T.F., Burridge, M.J., Mahan, S.M., 2000. Competence of the African tortoise tick, Amblyomma marmoreum (Acari: Ixodidae), as a vector of the agent of heartwater (Cowdria ruminantium). J Parasitol 86, 438-441.

Peter, T.F., Burridge, M.J., Mahan, S.M., 2002. Ehrlichia ruminantium infection (heartwater) in wild animals. Trends Parasitol 18, 214-218.

Peter, T.F., Deem, S.L., Barbet, A.F., Norval, R.A., Simbi, B.H., Kelly, P.J., Mahan, S.M., 1995. Development and evaluation of PCR assay for detection of low levels of Cowdria ruminantium infection in Amblyomma ticks not detected by DNA probe. J Clin Microbiol 33, 166-172.

Peter, T.F., Mahan, S.M., Burridge, M.J., 2001. Resistance of leopard tortoises and helmeted guineafowl to Cowdria ruminantium infection (heartwater). Vet Parasitol 98, 299-307.

Peter, T.F., Perry, B.D., O'Callaghan, C.J., Medley, G.F., Mlambo, G., Barbet, A.F., Mahan, S.M., 1999. Prevalence of Cowdria ruminantium infection in Amblyomma hebraeum ticks from heartwater-endemic areas of Zimbabwe. Epidemiol Infect 123, 309316.

Petney, T.N., Horak, I.G., Rechav, Y., 1987. The ecology of the African vectors of heartwater, with particular reference to Amblyomma hebraeum and Amblyomma variegatum. Onderstepoort J Vet Res 54, 381-395.

Pienaar, J.G., 1970. Electron microscopy of Cowdria (Rickettsia) ruminantium (Cowdry, 1926) in the endothelial cells of the vertebrate host. Onderstepoort J Vet Res 37, 67-78.

Pretorius, A., Collins, N.E., Steyn, H.C., van Strijp, F., van Kleef, M., Allsopp, B.A., 2007. Protection against heartwater by DNA immunisation with four Ehrlichia ruminantium open reading frames. Vaccine 25, 2316-2324.

Pretorius, A., van Kleef, M., Collins, N.E., Tshikudo, N., Louw, E., Faber, F.E., van Strijp, M.F., Allsopp, B.A., 2008. A heterologous prime/boost immunisation strategy protects against virulent $E$. ruminantium Welgevonden needle challenge but not against tick challenge. Vaccine 26, 4363-71. 
Provost, A., Bezuidenhout, J.D., 1987. The historical background and global importance of heartwater. Onderstepoort J Vet Res 54, 165-169.

Prozesky, L., 1987a. Heartwater. The morphology of Cowdria ruminantium and its staining characteristics in the vertebrate host and in vitro. Onderstepoort J Vet Res 54, 173-176.

Prozesky, L., 1987b. The pathology of heartwater. III. A review. Onderstepoort J Vet Res 54, 281-286.

Prozesky, L., Bezuidenhout, J.D., Paterson, C.L., 1986. Heartwater: an in vitro study of the ultrastructure of Cowdria ruminatium. Onderstepoort J Vet Res 53, 153-159.

Prozesky, L., Du Plessis, J.L., 1985. The pathology of heartwater. I. A study of mice infected with the Welgevonden strain of Cowdria ruminantium. Onderstepoort J Vet Res $52,71-79$.

Prozesky, L., Du Plessis, J.L., 1987. Heartwater. The development and life cycle of Cowdria ruminantium in the vertebrate host, ticks and cultured endothelial cells. Onderstepoort J Vet Res 54, 193-196.

Purchase, H.S., 1945. A simple and rapid method for demonstrating Rickettsia ruminantium (Cowdry, 1925) in heartwater brains. Vet Rec 57, 413-414.

Ramamoorthi, N., Narasimhan, S., Pal, U., Bao, F., Yang, X.F., Fish, D., Anguita, J., Norgard, M.V., Kantor, F.S., Anderson, J.F., Koski, R.A., Fikrig, E., 2005. The Lyme disease agent exploits a tick protein to infect the mammalian host. Nature 436, 573-577.

Reeves, W.K., Loftis, A.D., Nicholson, W.L., Czarkowski, A.G., 2008. The first report of human illness associated with the Panola Mountain Ehrlichia species: a case report. J Med Case Reports 2, 139.

Semu, S.M., Peter, T.F., Mukwedeya, D., Barbet, A.F., Jongejan, F., Mahan, S.M., 2001. Antibody responses to MAP $1 \mathrm{~B}$ and other Cowdria ruminantium antigens are down regulated in cattle challenged with tick-transmitted heartwater. Clin Diagn Lab Immunol 8, 388-396. 
Simbi, B.H., Peter, T.F., Burridge, M.J., Mahan, S.M., 2003. Comparing the detection of exposure to Ehrlichia ruminantium infection on a heartwater-endemic farm by the pCS20 polymerase chain reaction assay and an indirect MAP1-B enzyme linked immunosorbent assay. Onderstepoort J Vet Res 70, 231-235.

Simpson, B.C., Lindsay, M.S., Morris, J.R., Muirhead, F.S., Pollock, A., Prichard, S.G., Stanley, H.G., Thirlwell, G.R., Hunter, A.G., Bradley, J., 1987. Protection of cattle against heartwater in Botswana: comparative efficacy of different methods against natural and blood-derived challenges. Vet Rec 120, 135-138.

Stackebrandt, E., Goebel, B., 1994. Taxonomic note: a place for DNA-DNA reassociation and $16 \mathrm{~S}$ rRNA sequence analysis in the present species definition in bacteriology. Int J Syst Bacteriol 44, 846-849.

Steyn, H.C., Pretorius, A., McCrindle, C.M., Steinmann, C.M., Van Kleef, M., 2008. A quantitative real-time PCR assay for Ehrlichia ruminantium using pCS20. Vet Microbiol $131,258-65$.

Telfair, R. C. II. (1994). The Cattle Egret (Bubulcus ibis). In: The Birds of North America, No. 113 (eds. Poole, A. and Gill, F.), Philadelphia: The Academy of Natural Sciences; Washington, D.C.: The American Ornithologists' Union.

Uilenberg, G., 1982. Experimental transmission of Cowdria ruminantium by the Gulf coast tick Amblyomma maculatum: danger of introducing heartwater and benign African theileriasis onto the American mainland. Am J Vet Res 43, 1279-1282.

Uilenberg, G., 1983. Heartwater (Cowdria ruminantium infection): current status. Adv Vet Sci Comp Med 27, 427-480.

Uilenberg, G., 1990. Extension de la tique Amblyomma variegetum dans les Antilles : comment expliquer cette grave menace et que faire ? Rev Elev Med Vet Pays Trop 43, 297-299.

Uilenberg, G., Barré, N., Camus, E., Burridge, M.J., Garris, G.I., 1984. Heartwater in the Caribbean. Preventive Veterinary Medicine 2 , 255-267. 
Uilenberg, G., Camus, E., Barré, N., 1985. Quelques observations sur une souche de Cowdria ruminantium isolée en Guadeloupe (Antilles Françaises). Rev Elev Med Vet Pays Trop 38, 34-42.

Van de Pypekamp, H.E., Prozesky, L., 1987. Heartwater. An overview of the clinical signs, susceptibility and differential diagnoses of the disease in domestic ruminants. Onderstepoort J Vet Res 54, 263-266.

Van der Merwe, L., 1987. The infection and treatment method of vaccination against heartwater. Onderstepoort J Vet Res 54, 489-491.

Van Heerden, H., Collins, N.E., Brayton, K.A., Rademeyer, C., Allsopp, B.A., 2004a. Characterization of a major outer membrane protein multigene family in Ehrlichia ruminantium. Gene 330, 159-168.

Van Heerden, H., Steyn, H.C., Allsopp, M.T., Zweygarth, E., Josemans, A.I., Allsopp, B.A., 2004b. Characterization of the pCS20 region of different Ehrlichia ruminantium isolates. Vet Microbiol 101, 279-291.

Van Kleef, M., Neitz, A.W., De Waal, D.T., 1993. Isolation and characterization of antigenic proteins of Cowdria ruminantium. Rev Elev Med Vet Pays Trop 46, 157-164.

van Vliet, A.H., van der Zeijst, B.A., Camus, E. , Mahan, S.M., Martinez, D., Jongejan, F., 1995. Use of a specific immunogenic region on the Cowdria ruminantium MAP1 protein in a serological assay. J Clin Microbiol 33, 2405-2410.

Waghela, S.D., Rurangirwa, F.R., Mahan, S.M., Yunker, C.E., Crawford, T.B., Barbet, A.F., Burridge, M.J., McGuire, T.C., 1991. A cloned DNA probe identifies Cowdria ruminantium in Amblyomma variegatum ticks. J Clin Microbiol 29, 2571-2577.

Walker, J.B., Olwage, A., 1987. The tick vectors of Cowdria ruminantium (Ixodoidea, Ixodidae, genus Amblyomma) and their distribution. Onderstepoort J Vet Res 54, 353379 .

Wayne, L.G., Brenner, D.J., Colwell, R.R., Grimont, P.A.D., Kandler, O., Krichevsky, M.I., Moore, L.H., Moore, W.E.C., Murray, R.G.E., Stackebrandt, E.S.M.P., Truper, H.G., 
1987. Report on the ad hoc committee on reconciliation of approaches to bacterial systematics. Int J Syst Bacteriol 37, 463-464.

Wesonga, F.D., Mukolwe, S.W., Grootenhuis, J., 2001. Transmission of Cowdria ruminantium by Amblyomma gemma from infected African buffalo (Syncerus caffer) and eland (Taurotragus oryx) to sheep. Trop Anim Health Prod 33, 379-390.

Wikel, S.K., 1999. Tick modulation of host immunity: an important factor in pathogen transmission. Int J Parasitol 29, 851-859.

Yabsley, M.J., Loftis, A.D., Little, S.E., 2008. Natural and experimental infection of whitetailed deer (Odocoileus virginianus) from the United States with an Ehrlichia sp. closely related to Ehrlichia ruminantium. J Wildl Dis 44, 381-387.

Yu, X.J., McBride, J.W., Diaz, C.M., Walker, D.H., 2000. Molecular cloning and characterization of the 120-kilodalton protein gene of Ehrlichia canis and application of the recombinant 120- kilodalton protein for serodiagnosis of canine ehrlichiosis. J Clin Microbiol 38, 369-374.

Zeidner, N., Mbow, M.L., Dolan, M., Massung, R., Baca, E., Piesman, J., 1997. Effects of Ixodes scapularis and Borrelia burgdorferi on modulation of the host immune response: induction of a TH2 cytokine response in Lyme disease-susceptible $(\mathrm{C} 3 \mathrm{H} / \mathrm{HeJ})$ mice but not in disease-resistant (BALB/c) mice. Infect Immun 65, 3100-3106.

Zweygarth, E., Josemans, A.I., 2001. A chemically defined medium for the growth of Cowdria ruminantium. Onderstepoort J Vet Res 68, 37-40.

Zweygarth, E., Josemans, A.I., Van Strijp, M.F., Lopez-Rebollar, L., Van Kleef, M., Allsopp, B.A., 2005. An attenuated Ehrlichia ruminantium (Welgevonden stock) vaccine protects small ruminants against virulent heartwater challenge. Vaccine 23, 1695-1702.

Zweygarth, E., Josemans, A.I., Van Strijp, M.F., Van Heerden, H., Allsopp, M.T., Allsopp, B.A., 2002. The Kümm isolate of Ehrlichia ruminantium: in vitro isolation, propagation and characterization. Onderstepoort J Vet Res 69, 147-153. 
Zweygarth, E., Vogel, S.W., Josemans, A.I., Horn, E., 1997. In vitro isolation and cultivation of Cowdria ruminantium under serum-free culture conditions. Res Vet Sci 63, 161-164. 
Table 1. Wild ruminants known to be susceptible to E. ruminantium infection, either naturally or after experimental infection (Oberem and Bezuidenhout, 1987; Peter et al., 2002).

\begin{tabular}{|l|l|l|l|}
\hline \multicolumn{4}{|c|}{ Ruminant Hosts of E. ruminantium } \\
\hline \multicolumn{2}{|c|}{ African } & \multicolumn{2}{c|}{ Non - African } \\
\hline Common name & Scientific name & Common name & Scientific name \\
\hline African buffalo & Syncerus caffer & Barbary sheep & Ammotragus lervia \\
\hline Black wildebeest & Connochaetes gnu & Blackbuck & Antilope cervicapra \\
\hline Blesbuck & $\begin{array}{l}\text { Damaliscus dorcas } \\
\text { phillipsi }\end{array}$ & Chital & Axis axis \\
\hline Blue wildebeest & Connochaetes taurinus & Fallow deer & Cervus dama \\
\hline Bushbuck & Tragelaphus scriptus & Himalayan tahr & Hemitragus jemlahicus \\
\hline Duiker & Cephalophus sp. & Mouflon & Ovis orientalis \\
\hline Eland & Taurotragus oryx & Nilgai & Boselaphus tragocamelus \\
\hline Giraffe & Giraffa camelopardalis & Timor deer & Cervus timorensis \\
\hline Greater kudu & Tragelaphus strepsiceros & Water buffalo & Bubalus bubalis \\
\hline Lechwe & Kobus leche kafuensis & White tailed deer & Odocoileus virginianus \\
\hline Red hartebeest & Alcelaphus buselaphus & & \\
\hline $\begin{array}{l}\text { Scimitar-horned } \\
\text { oryx }\end{array}$ & Oryx dammah & & \\
\hline Sitatunga & Tragelaphus spekii & & \\
\hline Springbuck & Antidorcas marsupialis & & \\
\hline Steenbok & Raphicerus campestris & & \\
\hline
\end{tabular}


Table 2. Data for eight different srRNA genotypes of E. ruminantium.

\begin{tabular}{|l|l|l|l|l|l|l|l|}
\hline \multirow{2}{*}{ Genotype } & \multicolumn{3}{|l|}{ Origin } & \multicolumn{2}{l}{ Pathogenicity } & \multirow{2}{*}{ Accession } & Reference \\
\cline { 2 - 7 } & Geographical & Biological & Cattle & Sheep & Mice & No. & \\
\hline Ball3 & S. Africa & Bovine & + & + & - & AF355200 & (Haig, 1952) \\
\hline Gardel & Guadeloupe & A. hebraeum & + & + & 0 & U50832 & $\begin{array}{l}\text { (Uilenberg et al., } \\
\text { 1985) }\end{array}$ \\
\hline Kiswani & Kenya & Bovine & + & + & ND & None & $\begin{array}{l}\text { (Kocan et al., } \\
1987 b)\end{array}$ \\
\hline Mara 87/7 & S. Africa & A. hebraeum & + & + & + & AF368008 & $\begin{array}{l}\text { (Du Plessis et al., } \\
1989)\end{array}$ \\
\hline Omatjenne & Namibia & H. truncatum & - & $+/-$ & - & AF368012 & $\begin{array}{l}\text { (Du Plessis, } \\
\text { 1990) }\end{array}$ \\
\hline $\begin{array}{l}\text { Pretoria } \\
\text { North }\end{array}$ & S. Africa & Dog & ND & ND & ND & AF325175 & $\begin{array}{l}\text { (Allsopp and } \\
\text { Allsopp, 2001) }\end{array}$ \\
\hline Senegal & Senegal & Bovine & + & + & $+/-$ & X74250 & $\begin{array}{l}\text { (Jongejan et al., } \\
\text { 1988) }\end{array}$ \\
\hline Welgevonden & S. Africa & A. hebraeum & + & + & + & U49843 & $\begin{array}{l}\text { (Du Plessis, } \\
\text { 1985) }\end{array}$ \\
\hline
\end{tabular}

$+\quad$ Pathogenic

+/- Mildly pathogenic

- $\quad$ Non - pathogenic

$0 \quad$ Non - infective

ND Not done 
Table 3. Properties of two different srRNA genotypes of $E$. ruminantium obtained from the Kümm isolate.

\begin{tabular}{|l|l|l|}
\hline Property & Kümm 1 & Kümm 2 \\
\hline Growth in bovine endothelial cells & Yes & No \\
\hline Growth in canine macrophage-monocyte cells & Yes & No \\
\hline Growth in sheep mononuclear cells & Yes & Yes \\
\hline Regular subculture intervals & Yes & No \\
\hline Virulence in mice & + /- & + \\
\hline SrRNA genotype & Senegal & Omatjenne \\
\hline
\end{tabular}

$+\quad$ Pathogenic

+/- Mildly pathogenic 


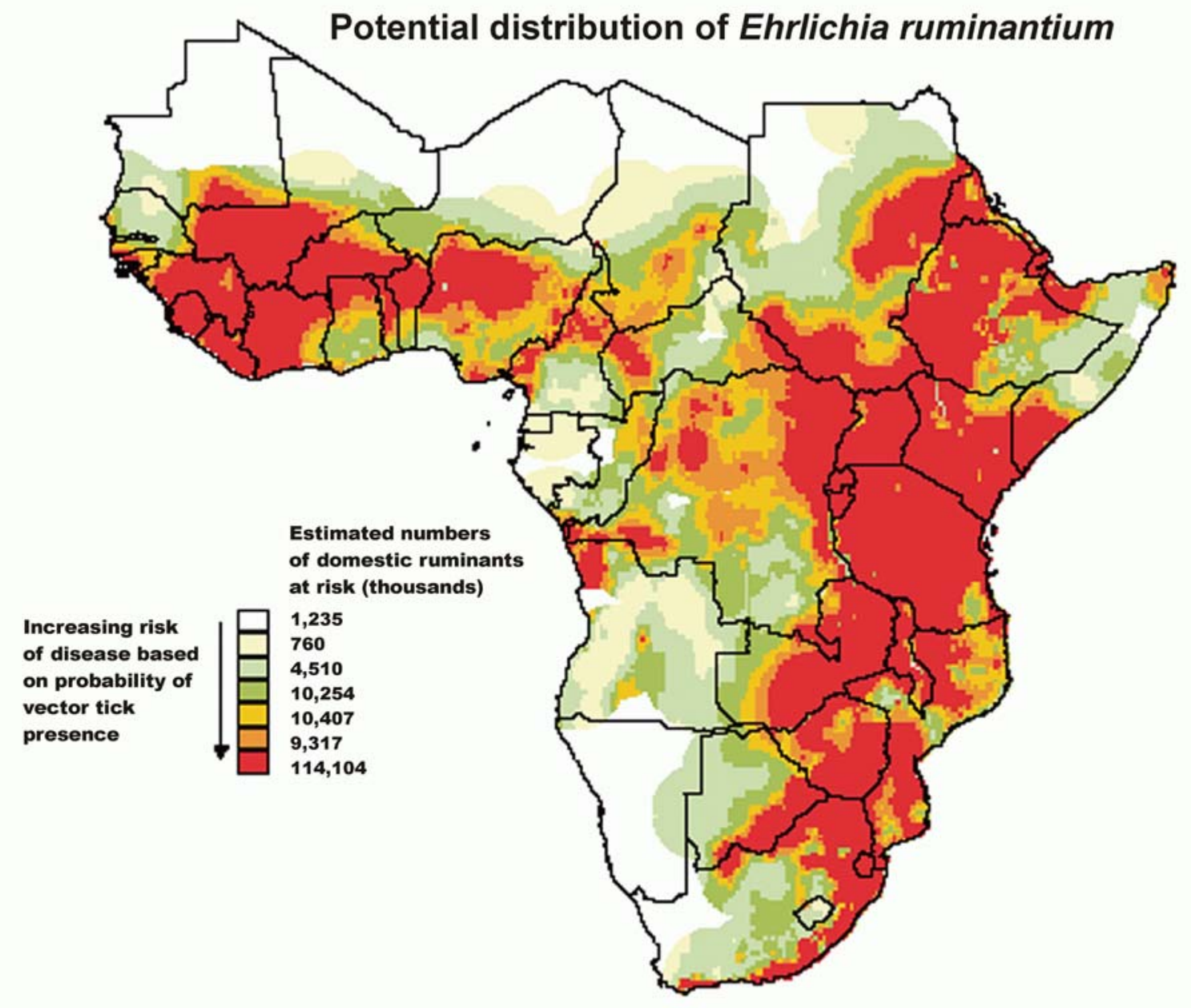

Figure 1. Potential distribution of Ehrlichia ruminantium in sub-Saharan Africa, based on habitat suitability for the vector tick species. Taken with permission from a poster by Minjauw B, Emsworth D, Wells C, Kruska R, Robinson T, and Nijbroek R., DFID-Animal Health Programme, CTVM, University of Edinburgh, Roslin, Midlothian, EH25 9RG, Scotland. 


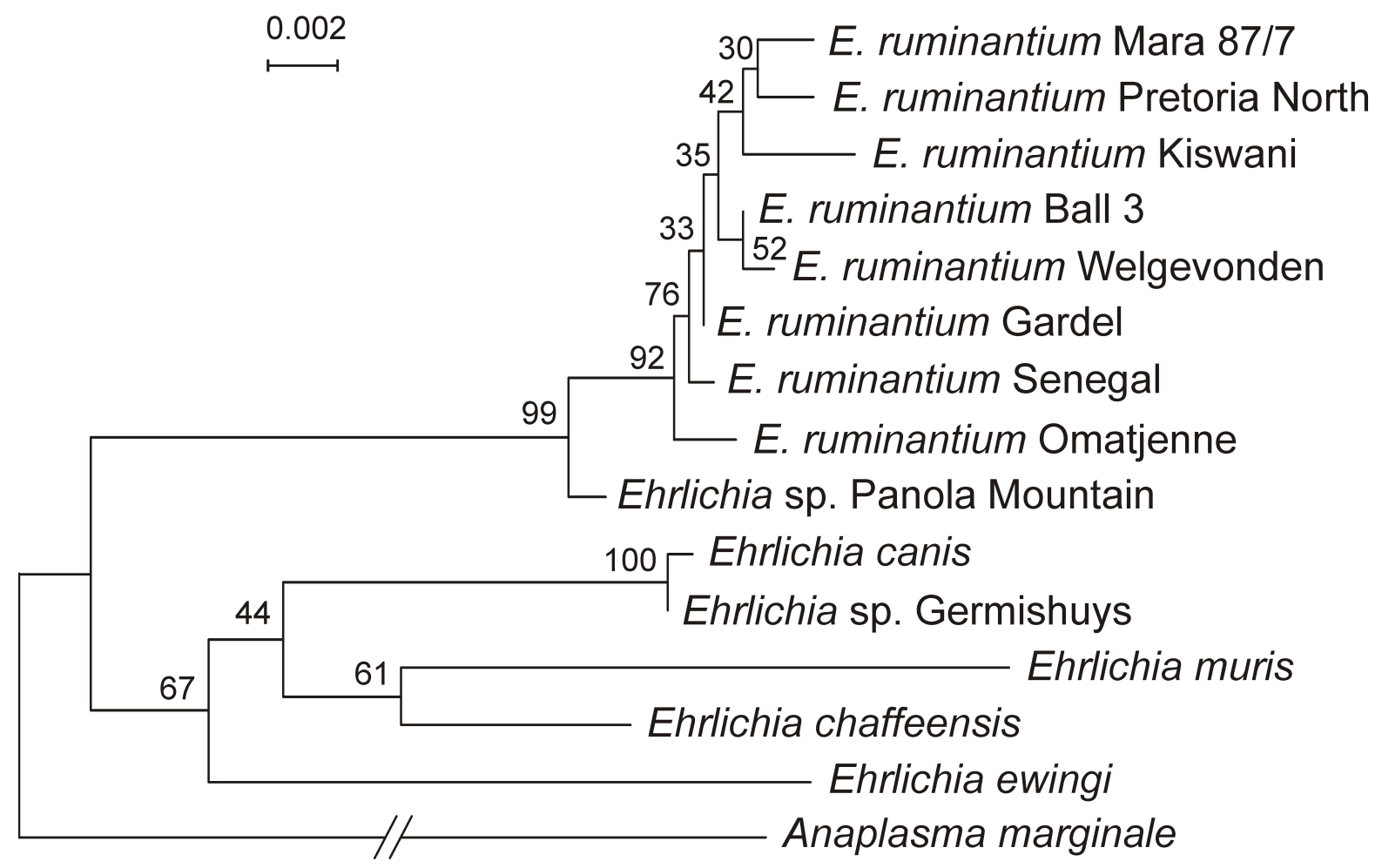

Figure 2. Maximum likelihood phylogenetic tree inferred from an alignment of small subunit ribosomal RNA gene sequences. The taxons are eight Ehrlichia ruminantium genotypes and six other species of Ehrlichia with Anaplasma marginale as the outgroup. The scale bar indicates 2 nucleotide substitutions per 1000 bases. 